\title{
G20 개발의제에 대한 평가와 향후과제
}

권해룡 $\quad \mathrm{G} 20$ 정상회의 준비위원회 무역·국제협력국장
목차
I. 머리말
II. G20 개발의제의 도입 배경 및 논의 경과
III. 서울 개발 컨센서스 및 다년간 행동계획 주요 내용
IV. G20 개발의제에 대한 평가

\section{I. 머리말}

지난 11월 G20 서울 정상회의는 세계경제의 주요 현안과 주요 G20 의제에 있어 많은 성과를 거 두면서 성공리에 개최되었다. 이를 통해, 위기상황이 끝나가면서 주요국간 정책공조가 약화되는 것이 아니냐는 우려를 불식하고, 세계경제협력을 위한 최상위 협의체(premier forum)로서의 G20 의 유효성을 확인하는 기회가 되었다. 2008년 금융위기 대응을 위한 목적으로 출범한 G20 정상회 의는 그동안 세계경제 회복과 안정성장 기반 강화를 위한 거시경제 공조, 금융시스템 강화를 위한 금융규제 및 국제금융기구 개혁 등을 주요 의제로 논의해 왔다. 서울 정상회의에서도 글로벌 불균 형 완화를 위한 정책공조를 강화하고, 은행 자본·유동성 규제 강화, IMF 쿼타 및 거버넌스 개혁 에 합의하는 등의 성과가 있었다.

이와 함께, G20 서울 정상회의에서 중요한 의미가 있는 성과의 하나로는 개발 문제가 처음으로 $\mathrm{G} 20$ 의 주요 의제로 논의되어 “서울 개발 컨센서스"와 “다년간 개발 행동계획”에 합의한 것을 들 수 있다. 이는 G20 정상회의의 의제가 위기상황 대응을 위한 거시경제 정책공조, 금융개혁 등 이 슈에서 국제사회의 주요 과제인 개발 등으로 확대되어, 향후 글로벌 거버넌스 체제로서 G20의 역 
할이 더욱 강화될 것임을 시사한다. 또한, $\mathrm{G} 20$ 의 개발 의제 논의는 국제개발체제 차원에서도 매 우 큰 의미를 가진다. 이 글에서는 G20 개발의제의 도입 배경 및 논의 경과, 서울 정상회의 개발 분야 주요 성과 및 평가, 앞으로의 과제, 우리나라 개발외교정책에 대한 시사점 등을 살펴보도록 하겠다.

\section{G20 개발의제의 도입 배경과 논의 경과}

\section{G20 개발의제의 도입 배경}

G20 개발 의제는 금융안전망 이슈와 함께 코리아 이니셔티브로 알려져 있다. 그만큼 우리나라가 개발의제 도입 및 성과 도출 과정에서 주도적 역할을 했다고 할 수 있다. 국제사회가 당면한 핵심 과제의 하나인 개발은 G20 정상회의에서도 여러 형태로 논의되어 왔다. 특히, 금융위기로 큰 영 향을 받은 최빈국과 취약계층을 지원하는 차원에서 워싱턴, 런던, 피츠버그 및 토론토 정상회의에 서 식량안보, 저소득국에 대한 다자개발은행의 대출재원 확대, 금융소외계층에 대한 금융접근성 확대 등 이슈가 다루어졌다. 그러나 개발 의제가 $\mathrm{G} 20$ 의 중심 의제의 하나로 종합적으로 논의되게 된 것은 서울 정상회의가 처음이라고 할 수 있다.

우리나라가 G20 개발 의제 도입을 추진한 것은 G20 정상회의가 위기극복 이후에도 국제사회의 주요 과제를 다루는 핵심 거버넌스 체제로 발전하도록 기여하고자 하는 외교목표와 밀접히 관련되 어 있다. G20 정상회의는 당초 2008년 금융위기 극복방안 논의를 위한 한시적인 성격의 회의로 개최되었다. G20이 긴밀한 국제공조를 통해 세계경제의 예상보다 빠른 회복에 기여하는 등 효과 성이 입증되면서, 2009년 11월 개최된 피츠버그 정상회의에서 G20 정상회의가 세계경제협력을 위 한 최상위 협의체로 지정되었고 정상회의의 연례개최에 합의하였다. G20이 최상위 협의체로서의 역할을 제대로 수행하기 위해서는 위기대응과 관련되는 문제뿐만 아니라 보다 장기적으로 세계경 제의 지속가능하고 균형된 발전에 기여할 수 있는 새로운 의제를 발굴하고 성과를 도출해 나갈 필 요가 있다. 그렇게 함으로써 G20의 역할이 공고해지고, 이에 따라 글로벌 거버넌스 체제에서 G20 회원국으로서 우리나라의 역할을 강화할 수 있을 것이다.

한편, 우리나라는 G20이 의제를 급격하게 확대하여 제대로 이행하지 못하게 되기보다는, 국제사 회에 기여할 수 있는 소수의 의제를 선별하여 실질적인 성과를 도출하는 것이 바람직하다고 생각 했다. 또한, 회원국뿐만이 아니라 170 개국이 넘는 비회원국의 관심사도 다루어 나갈 때 G20이 국 
제사회에서 차지하는 위상에 걸맞은 역할을 하고 국제사회의 지지를 얻을 수 있을 것이라고 판단 하였다. 이러한 전략적 고려에 따라 우리나라는 서울 정상회의 준비의 일환으로 개발 의제를 적극 적으로 추진하게 된 것이다.

\section{2. 논의 경과}

\section{1) 토론토 정상회의까지}

우리나라는 2010년 상반기에 G20 정상회의에서 개발 의제 도입 필요성에 대해 G20 회원국들과 국제사회의 지지를 확보하기 위한 적극적인 노력을 전개하였다. G20에서의 개발 문제 논의에 대 해 처음부터 모든 나라들이 찬성했던 것은 아니다. 무엇보다도 $\mathrm{UN}, \mathrm{OECD}, \mathrm{G} 8$ 등 여러 국제기구 와 포럼에서 개발 문제를 다루고 있고 새천년개발목표(MDG)라는 국제사회의 핵심 개발 아젠다가 추진되고 있는데, G20이 또다시 개발 의제를 다루는 것이 불필요한 중복과 비효율성을 초래하는 것이 아니냐는 비판적인 시각이 있었다. 이에 대해 우리나라는 G20이 핵심과제로 추진하고 있는 세계경제의 지속가능·균형성장을 위해서는 개발 문제를 함께 고려하는 것이 필요하다는 점을 강 조하였다. 또한, G20만이 가지고 있는 비교우위를 활용하여 국제 개발 논의에 있어 부가가치를 창출할 수 있을 것이라는 점을 설득하였다.

G20은 글로벌 불균형을 해소하고 세계경제의 강하고, 지속가능하며, 균형된 성장을 촉진하는 것 을 중요한 목표의 하나로 하고 있다. 이러한 논의 과정에서 상당수 개도국들은 개발 격차의 해소 도 중요한 과제가 되어야 함을 지적했다. 사실 개발 격차 해소와 글로벌 불균형 해소는 밀접하게 연계되어 추진될 수 있다. 금융위기와 재정악화 등으로 인해 선진국의 성장동력이 소진된 상황에 서 개도국의 경제성장은 새로운 수요를 창출하여 글로벌 불균형 해소에 기여할 수 있는 것이다. 이와 같이, G20에서의 개발 논의는 G20의 핵심과제와 연계하여 경제성장에 중점을 두어 추진함 으로써, 기존 개발 논의를 반복하는 것이 아니라 보완할 수 있을 것이다. 또한, G20에는 G7으로 대표되는 전통적인 공여국뿐만 아니라, 경제성장을 달성한 신흥경제국들이 같이 포함되어 있어 보 다 균형된 시각에서 개발 문제에 대한 논의가 가능하다는 장점이 있다. 실제로 국제 개발 분야에 서 이들 신흥경제국들이 주요 행위자로 부상하고 있는 가운데, 이들을 배제하고 의미있는 개발 논 의를 진행한다는 것이 이미 어려워졌다고 할 수 있다.

이와 같이 G20 개발의제 추진의 필요성과 의미를 설명하는 노력을 통해 G20 회원국들 사이에서 도 개발 문제 논의를 지지하는 입장이 확산되었으며, 비회원국을 포함한 국제사회도 $\mathrm{G} 20$ 의 개발 의제 논의에 대해 많은 지지를 보내주었다. 마침내 2010.6월 토론토에서 개최된 정상회의에서 개 
발 의제를 $\mathrm{G} 20$ 의 주요 의제로 다루기로 합의하였다. 정상들은 개발 실무그룹을 설치하여 경제성 장과 성장복원력 제고에 중점을 둔 개발 아젠다와 다년간 행동계획을 작성하도록 하고 이를 서울 정상회의에서 채택하기로 합의하였다.

\section{2) 서울 정상회의 준비}

토론토 정상회의 이후 11 월 서울 정상회의까지는 불과 4 개월을 약간 넘는 기간밖에 없었다. 이러 한 짧은 기간 중에 개발 실무그룹을 구성하고 성과물을 도출해 내어야 했다. 우선 토론토 정상회 의가 종료된 직후, 개발의제 추진을 위한 협의체로 우리나라와 남아공의 G20 셰르파(Sherpa)를 공동의장으로 하는 고위급 개발 실무그룹(Working Group)을 구성하였으며, 필자는 우리나라 수 석대표로 동 실무그룹 논의에 참석하였다. 동 실무그룹에는 $\mathrm{UN}$, 세계은행 등 개발 관련 국제기구 와 지역개발은행이 기술자문그룹(Technical Suport Group) 자격으로 참석하도록 하였다.

제 1 차 개발 실무그룹회의가 7 월 19 일 - 20 일간 서울에서 개최되었다. 이 회의에서는 $\mathrm{G} 20$ 의 성장 중심 개발의제 추진방향과 인프라, 인적자원 개발 등 주요 추진분야(pillar)에 대한 공감대를 확인 하고 서울 정상회의까지의 작업계획을 구체화하였다. 또한, G20 개발의제 추진 원칙(principles) 을 마련하고, 이를 기초로 행동계획(action plan)을 작성하기로 합의하였다. 이에 따라, 공동의장 의 주도로 회원국들은 G20 개발의제가 지향할 경제성장 중심 등 6대 원칙을 작성하고, 9월 7일 개최된 개발 실무그룹 텔레컨퍼런스를 통해 동 원칙에 잠정 합의하였다.

개발 행동계획 작성을 위한 작업은 국제기구와 회원국들의 적극적인 참여하에 진행되었다. 우선 기술자문그룹으로 개발 실무그룹에 참여하는 $\mathrm{UN}$, 세계은행, $\mathrm{OECD}, \mathrm{UNCTAD}, \mathrm{WTO}, \mathrm{ILO}$ 등 개 발 관련 국제기구와 $\mathrm{ADB}, \mathrm{AfDB}, \mathrm{IaDB}, \mathrm{IsDB}$ 등 지역개발은행이 소관 전문분야에서 행동계획에 포함될 구체 제안을 제출하였다. 한편 회원국들도 국제기구의 제안을 참고하여 국별로 관심있는 분야에서 행동계획 제안을 제출하였다. 이러한 결과 100 개가 넘는 제안들이 국제기구와 회원국들로 부터 접수되었다. 개발 실무그룹은 인프라 등 각 분야(pillar)별로 2개국 이상의 조정국(facilitator) 을 선정하여 분야별 행동계획을 통합하는 작업을 주도하도록 하였다. 이러한 과정에서 제출된 제 안이 G20 개발 원칙(principles)에 얼마나 부합하느냐를 중요한 선정 기준으로 활용하였다. 이를 통해 분야별로 1-3개의 과제들을 선정하여, 이를 기초로 행동계획 초안을 마련하였다. 9월 30일 - 10 월 1 일간 개최된 제 2 차 개발 실무그룹회의에서는 향후 서울 개발 컨센서스가 되는 기본문서 와 다년간 행동계획(안)에 대한 잠정적인 합의가 이루어졌고, 10 월 개최된 셰르파 회의에서 이를 승인하고 정상회의에 제출하기로 하였다. 


\section{3) 서울 정상회의}

이러한 준비 과정을 거쳐 11 월 11 일 - 12 일간 개최된 G20 서울 정상회의에서는 개발 문제가 별도 의 독립된 세션에서 논의되는 등 G20 차원에서는 최초로 주요 의제로 논의되었다. 참가국 정상과 $\mathrm{UN}$, 세계은행 등 국제기구 수장들은 G20 정상회의에서 개발 문제가 주요 의제로 논의되게 된 것 을 높이 평가하였다. 반기문 UN 사무총장은 강력한 정치적 의지를 가지고 $\mathrm{MDG}$ 이행에 중점을 둘 것과 개발재원 공약 이행의 중요성을 강조하였다. 졸릭 세계은행 총재는 개발이 보다 많은 성 장의 축을 구축하기 위한 투자라고 강조하면서, 인프라에 대한 투자가 단기적으로는 고용과 수요 를 창출하며, 중장기적으로는 개발의 장애요인을 해소하여 생산성 향상과 성장으로 이어질 것이라 고 지적하였다. 오바마 미국 대통령은 개도국의 성장을 위한 환경 조성의 중요성을 강조하였으며, 한국이 성공적으로 발전할 수 있었던 것도 공적원조와 함께 민간자본의 유입을 촉진할 수 있도록 경제 구조개혁을 할 수 있었기 때문이라고 지적하였다. 한편, 서울 정상회의에 초청국 자격으로 참석한 에티오피아의 제나위 총리는 개발에 관한 “서울 컨센서스"는 곧 “아프리카 컨센서스”라고 언급하면서 서울 컨센서스가 향후 다자개발은행을 포함한 모든 개발 행위자에게 개발 관련 행동 (action)의 기초가 되기를 희망하였다.

이러한 논의를 거쳐 서울 개발 컨센서스와 다년간 개발 행동계획이 채택되었다. 정상들은 합의사항 이행의 중요성을 강조하면서 개발 행동계획을 적기에 완전하게 이행하겠다고 약속하였다. 이를 위해 개발 실무그룹으로 하여금 다년간 행동계획의 이행을 모니터링하도록 임무를 부여하고, 2011년 프랑 스 정상회의에서 이행 진전상황을 점검하고 추가적으로 필요한 조치를 취하기로 하였다. 이를 통해, 개발이 G20의 주요 아젠다로 지속적으로 논의될 수 있는 기반을 마련한 것이다. 또한, 정상들은 $\mathrm{MDG}$ 달성을 위한 결의를 재확인하고 각국의 공적개발원조(ODA) 공약을 이행하겠다고 약속하였다.

\section{III. 서울 개발 컨센서스와 다년간 행동계획의 주요 내용}

\section{1. 서울 개발 컨센서스}

“다함께 성장을 위한 서울 개발 컨센서스(Seoul Development Consensus for Shared Growth)" 는 G20 개발의제 추진 필요성, 목표, 원칙, 주요 분야 등을 제시하고 있는 일종의 G20 개발 헌장 이라고 할 수 있다. 서울 개발 컨센서스는 G20이 공여국, UN 기구, 다자개발은행의 역할을 보완 하여 개도국, 특히 저소득국의 MDG 달성을 지원하는 역할을 수행해야 함을 지적하면서, G20 개 발의제가 개도국의 경제성장 지원을 통해 빈곤감소, 인권개선, 고용창출 등에 기여하는 것을 목표 
로 하고 있음을 밝히고 있다. 또한, 성장을 통한 개도국의 소비 증대 및 개도국으로의 투자를 통 해 새로운 총수요를 창출하여, 글로벌 불균형 해소와 세계경제의 지속가능하고 균형된 성장에 기 여할 수 있음을 지적하고 있다. 아울러, 개발목표 달성의 성공을 위해 모든 경우에 항상 적용되는 (one-size-fits-all) 방법은 없으며, 자국의 수요와 환경에 적합한 개발 전략을 수립하여 이행하 는 데 있어 개도국들이 주도적인 역할을 하여야 함을 강조하고 있다.

서울 컨센서스에서 정상들은 이같은 목표 달성을 위해 G20 개발 논의의 6개 원칙(G20 Development Principles)을 다음과 같이 제시하고 있다. 첫째, 포용적이고, 지속가능하며, 복원력 있는 경제성 장에 중점을 두어 개발목표를 달성한다. 둘째, 개도국, 특히 저소득국가와의 동등한 파트너십을 중시한다. 셋째, 세계적이고 지역적인 체계적인 이슈에 대한 공동 대응을 우선시한다. 넷째, 고용 과 부 창출에 있어서의 민간의 참여와 혁신을 촉진한다. 다섯째, G20의 비교우위를 활용하여 기 존 개발논의를 보완하고 부가가치를 창출한다. 여섯째, 실질적인 성과 창출에 중점을 둔다.

〈표 1〉 G20 개발의제 6대 원칙

\begin{tabular}{|c|c|}
\hline 원 칙 & 주요 내용 \\
\hline $\begin{array}{c}\text { 경제성장 중심 } \\
\text { (Focus on economic growth) }\end{array}$ & $\begin{array}{l}\text { - 견실하고 지속가능한 경제성장은 MDG 달성을 위한 저소득국의 } \\
\text { 능력을 강화 } \\
\text { - 포용적이고, 지속가능하며, 복원력있는 경제성장 잠재력을 증대 } \\
\text { 시킬 수 있는 개발정책 추진 }\end{array}$ \\
\hline $\begin{array}{c}\text { 글로벌 개발 파트너십 } \\
\text { (Global development partnership) }\end{array}$ & $\begin{array}{l}\text { - 개도국, 특히 저소득국 스스로의 개발정책의 중요성을 인식하고, } \\
\text { 개도국의 주인의식을 존중하면서 동동한 파트너로서 개발협력 } \\
\text { - G20과 저소득국간 강하고, 책임있고, 투명한 개발 파트너십을 } \\
\text { 촉진 }\end{array}$ \\
\hline $\begin{array}{c}\text { 세계적·지역적 차원의 } \\
\quad \text { 체계적 이슈 대응 } \\
\text { (Global or regional systemic issues) } \\
\end{array}$ & $\begin{array}{l}\text { - 세계적 또는 지역적 차원의 이슈에 우선순위를 부여하여 대응 } \\
\text { - 공동의 조치가 필요한 체계적인 이슈 대응에 중점 }\end{array}$ \\
\hline $\begin{array}{c}\text { 민간 부문의 참여 } \\
\text { (Private sector participation) }\end{array}$ & $\begin{array}{l}\text { - 개발 지식, 기술, 고용창출에 있어 민간의 역할을 인식하고, 민간 } \\
\text { 부문의 참여와 혁신을 촉진 } \\
\text { - 리스크 요인 완화, 투자환경 개선, 시장규모 확대 등을 통해 민 } \\
\text { 간자본 유입 촉진 }\end{array}$ \\
\hline $\begin{array}{c}\text { 상호보완성 } \\
\text { (Complementarity) }\end{array}$ & $\begin{array}{l}\text { - 기존 개발 이니셔티브와의 중복을 피하고 이를 보완 } \\
\text { - G20이 비교우위를 가지고 있으며 부가가치를 창출할 수 있는 } \\
\text { 분야에 중점 }\end{array}$ \\
\hline $\begin{array}{c}\text { 성과 지향 } \\
\text { (Outcome orientation) }\end{array}$ & $\begin{array}{l}\text { - 개도국의 성장에 대한 장애요인을 해소할 수 있는 실행가능하고 } \\
\text { 실용적이며 실질성과를 도출할 수 있는 조치에 중점 } \\
\text { - 적절한 책임성 프레임워크를 통하여 개발 행동계획 이행을 모 } \\
\text { 니터링 }\end{array}$ \\
\hline
\end{tabular}


이와 같은 원칙을 고려하여, 인프라, 인적자원개발, 무역, 민간투자 및 고용창출, 식량안보, 성장 복원력(growth with resilience), 국내개발재원 확충, 금융소외계층 포용(financial inclusion), 개 발지식 공유(knowledge sharing) 등 9 개의 핵심 분야를 선정하였다. 이들 분야는 한국이 그간의 개발 과정에서 빈곤을 해소하는 데 결정적으로 영향을 준 분야이며, 개도국이 최근의 세계경제 위 기를 극복하고 지속가능하고 복원력 있는 성장의 길로 가는데 중요한 분야이기 때문에 선정된 것 이라고 할 수 있다.

\section{2. 다년간 개발 행동계획}

"다년간 개발 행동계획(Multi-Year Action Plan on Development)"은 서울 개발 컨센서스가 지향 하는 목표를 이행하기 위한 구체적인 행동계획을 제시하고 있다. 상기 9개 핵심분야별로 1-3개씩 16 개의 행동계획이 채택되었으며, 상호간에 밀접히 연계된 이들 분야에서의 개혁을 통해 개도국들 이 지속가능하고 복원력 있는 경제성장을 촉진하기 위한 환경을 조성할 수 있기를 기대하고 있다.

다년간 개발 행동계획은 다음과 같은 특징을 가지고 있다. 우선 분야별로 기존에 진행되고 있던 이니셔티브와 연계하여 광범위한 개발 행위자의 참여를 통한 공조를 추구하고 있다. 예를 들면, 인프라의 경우, 세계은행과 지역개발은행에게 개도국, 특히 저소득국의 국내 및 지역 인프라 투자 를 확대시키기 위한 행동계획을 작성하도록 요청하고, 아프리카, 아시아 등의 기존 인프라 프로그 램1)을 보다 발전시켜 자금조달이 가능한 지역 인프라 사업을 제시하도록 하고 있다. 식량안보의 경우, 라퀼라 식량안보 이니셔티브(AFSI), 글로벌 농업·식량안보 프로그램(GAFSP) 등 식량안보 및 지속가능한 농업개발에 대한 기존 공약을 이행할 필요성을 강조하는 한편, 유엔식량농업기구 (FAO), 국제농업개발기금(IFAD), IMF, OECD, UNCTAD, 세계식량계획(WFP), WTO, 세계은행 등 과 함께 식량가격 변동성 완화를 위한 G20 차원의 정책대안을 발굴하도록 하고 있다.

다음으로는 개별 행동계획별로 이행 담당기관과 시한을 명확히 제시하고 있다. 특정 행동계획에 대해 최종 목표시한뿐만 아니라 이를 달성하기 위한 중간단계를 구체화하고 이에 대해서도 시한을 설정함으로써 체계적으로 이행해 나가도록 하고 있다. 또한, 행동계획의 이행으로 동 분야의 과제 가 종료되는 것이 아니라, 행동계획 이행결과를 발전시켜 나갈 수 있는 후속조치도 발굴하고 추가 적으로 필요한 결정을 내릴 수 있도록 하고 있다. 이는 다년간 행동계획이 일회성 조치가 아니라 글자그대로 여러 해에 걸쳐 이행되고 심화되어 나가도록 함으로써 분야별로 추구하고 있는 목표들 을 달성하도록 하고 있는 것이다.

1) Infrastructure Project Preparation Faciliy (IPPF), African Water Facility (AWF), Asian Infrastructure Financing Initiative (AIFI) 등 
〈표 2〉 다년간 개발 행동계획 주요 내용

\begin{tabular}{|c|c|}
\hline 분 야 & 행동 계획 \\
\hline $\begin{array}{c}\text { 인프라 } \\
\text { (Infrastructure) }\end{array}$ & $\begin{array}{l}\text { (1) 포괄적인 인프라 행동계획 마련 } \\
\text { - 인프라 수요 및 소요재원 파악, 인프라 투자 장애요인 해소, 저소득국의 } \\
\text { 인프라 투자환경 개선, 지역 인프라 투자 활성화 } \\
\text { (2) 인프라 투자를 위한 G20 고위급 패널 설치 } \\
\text { - 공공 및 민간 자본을 활용한 인프라 투자재원 확충방안 }\end{array}$ \\
\hline $\begin{array}{c}\text { 인적자원개발 } \\
\text { (Human Resource } \\
\text { Development) }\end{array}$ & $\begin{array}{l}\text { (1) 국제적으로 비교가능한 직업기술 측정지표 개발 } \\
\text { - 직업기술 개발을 통한 개도국의 고용 및 생산성 증진 } \\
\text { (2) 국가 직업기술 전략 강화 } \\
\quad \text { - 저소득국의 직업기술 개발 국가전략 지원 }\end{array}$ \\
\hline $\begin{array}{l}\text { 무역 } \\
\text { (Trade) }\end{array}$ & $\begin{array}{l}\text { (1) 무역역량 배양 및 시장접근 강화 } \\
\text { - 최빈개도국 상품에 대한 무관세무쿼터 시장접근 확대 } \\
\text { - 무역을 위한 원조를 2011년 이후 최소한 2006-2008년간 평균 수준으 } \\
\text { 로 유지 } \\
\text { - 아프리카의 역내 교역 확대에 대한 장애요소 확인 }\end{array}$ \\
\hline $\begin{array}{l}\text { 민간투자 및 고용창출 } \\
\text { (Private Investment } \\
\text { and Job Creation) }\end{array}$ & $\begin{array}{l}\text { (1) 책임있고 가치를 창출하는 민간투자 및 고용창출 지원 } \\
\text { - 청년실업 등 사회적 과제 해결에 기여하는 기업 혁신사례 경진대회 개최 } \\
\text { 요청 } \\
\text { - 개도국의 기업투자환경 개선, 민간투자의 부가가치 극대화, 투자 규제 } \\
\text { 체제 지원 위한 행동계획 마련 지원 }\end{array}$ \\
\hline $\begin{array}{c}\text { 식량안보 } \\
\text { (Food Security) }\end{array}$ & $\begin{array}{l}\text { (1) 정책 일관성 및 조율 강화 } \\
\text { - 식량안보와 농업생산성 증대에 관한 G20 공약 이행 } \\
\text { (2) 식량가격 변동성 위험 완화 및 취약계층 보호 } \\
\text { - 농산물 가격변동성에 연관된 위험을 관리 및 완화하는 G20 차원의 정 } \\
\text { 책대안 발굴 }\end{array}$ \\
\hline $\begin{array}{c}\text { 복원력 있는 경제성장 } \\
\text { (Growth with Resilience) }\end{array}$ & $\begin{array}{l}\text { (1) 개도국의 사회보장제도 강화 지원 } \\
\text { - 사회보호 모범사례 가이드라인 마련 및 지식공유 통한 확산 } \\
\text { (2) 국제송금 흐름 활성화 } \\
\text { - 국제 평균 송금비용 인하 추진 }\end{array}$ \\
\hline $\begin{array}{l}\text { 금융소외계층 포용 } \\
\text { (Financial Inclusion) }\end{array}$ & $\begin{array}{l}\text { (1) 금융소외계층 포용을 위한 글로벌 파트너십 설립 } \\
\text { - 정보공유, 조정, 모니터링, 지금조달 등 역할 수행 } \\
\text { (2) 중소기업 자금지원 경진대회와 금융소외계층 포용을 위한 자금지원체계 } \\
\text { - 중소기업에 대한 민간자금 지원을 촉진하는 혁신적인 모델을 제시한 우 } \\
\text { 수사례를 선정하고, 동 모델의 확산을 위한 자금지원체계를 설립 } \\
\text { (3) 금융소외계층 포용을 위한 행동계획 채택 및 실행 }\end{array}$ \\
\hline $\begin{array}{c}\text { 국내개발재원 확충 } \\
\text { (Domestic Resource } \\
\text { Mobilization) }\end{array}$ & $\begin{array}{l}\text { (1) 보다 효과적인 조세체제 개발 지원 } \\
\text { - 개도국 조세행정기관의 효율성·투명성 제고, 세원 확충 및 조세회피· } \\
\quad \text { 탈세 방지 위한 조세정책 역량강화 } \\
\text { (2) 국내 조세수입 누락방지 지원 } \\
\text { - 개도국의 세수기반 감소를 방지하기 위한 작업 강화 }\end{array}$ \\
\hline $\begin{array}{c}\text { 개발지식 공유 } \\
\text { (Knowledge Sharing) }\end{array}$ & $\begin{array}{l}\text { (1) 개발지식 공유의 효과성 제고 및 범위 확대 } \\
\text { - 개발지식 공유 확대를 위한 정책권고 요청 }\end{array}$ \\
\hline
\end{tabular}




\section{G20 개발의제에 대한 평가}

\section{1. 개발 문제에 대한 $\mathrm{G} 20$ 의 접근방법 : 역량배양을 통한 경제성장 중심}

$\mathrm{G} 20$ 서울 정상회의 개발 분야의 성과는 국제 개발논의에 있어 상당한 의미를 가지게 될 것으로 평가된다. 무엇보다도 서울 컨센서스와 행동계획은 전통적으로 개발 이슈를 주도해 왔던 G8 국가

들과 새로운 공여국으로 부상한 주요 신흥경제국, $\mathrm{UN}$, 세계은행, $\mathrm{OECD}$ 등 주요 개발 관련 기구, 서울 정상회의 및 제 2 차 개발 실무그룹회의에 참석한 에티오피아, 말라위, 베트남 등 개도국과의 협의를 통하여 만들어 낸 결과물이라는 데에서 그 의미가 크다. 따라서, 개발 문제에 대해 G20이 어떠한 접근방법을 채택하고 있는지 살펴보는 것은 향후 국제 개발논의의 진전방향을 가늠하는 데 있어서도 큰 시사점을 주게 될 것이다.

G20 개발의제는 보다 중장기적인 관점에서 개도국들이 개발목표를 달성할 수 있도록 능력을 배양 하고 여건을 조성하는 데 중점을 두고 있다. 이러한 접근방법은 위에서 설명한 서울 개발 컨센서 스와 다년간 행동계획에 잘 구현되어 있다. 아시아 신흥국들과 같이 인프라, 인적자원개발, 무역 등 개발에 성공한 국가들이 활용하였던 다양한 정책수단을 동원하고 있으며, 특히 개도국들의 성 장잠재력을 확충할 수 있는 정책지원에 중점을 두고 있다.

이러한 접근방식은 직접적인 원조에 비해서 효과가 즉각적으로 나타나지 않을 수는 있으나, 성공 적으로 추진될 경우 그 성과의 지속가능성이나 파급력 면에서 훨씬 큰 효과를 거둘 수 있을 것으 로 생각된다. 상호 밀접하게 연관되어 있는 분야에서 종합적 정책수단을 동원함으로써 여러 분야 에 걸쳐 균형된 발전을 할 수 있도록 하며, 분야간 시너지를 기대할 수 있다. 예를 들어 인프라 구축, 해외 시장접근 확대, 농업생산성 향상이 동시에 이루어지게 될 경우, 농산물 수출을 증대할 수 있게 되어 이에 따른 추가 소득 등 국가경제에 미치는 긍정적 파급효과가 더욱 커지게 될 것이다.

\section{2. 기존 국제 개발논의 보완}

G20 개발의제를 포함한 국제사회의 다양한 개발 논의가 궁극적으로 지향하는 바는 공동의 개발목 표를 달성하는 것이다. 이러한 국제 개발목표는 $\mathrm{MDG}$ 에 잘 제시되어 있다고 할 수 있으며, $\mathrm{MDG}$ 는 여러 분야별로 다양한 수단의 효과적 조합을 통해 달성할 수 있을 것이다. G20 개발의제는 개 도국의 역량배양을 통한 경제성장을 통해 MDG 달성에 기여하고자 하고 있다. MDG와 G20 개발 의제와의 관계를 단순화하여 보는 시각에서는 $\mathrm{MDG}$ 는 개발이 지향하는 목표를 제시하고 있고 
G20 개발의제는 그 달성수단에 중점을 두고 있다고 할 수도 있겠으나, 그렇다고 해서 MDG와 G20 개발의제를 목표와 수단으로 이분법적으로 구분하는 것은 균형된 개발정책 추진을 위해서 바 람직하지 않을 수 있다. 교육, 보건 등 $\mathrm{MDG}$ 달성에 있어서의 진전은 인적자원개발을 통하여 경 제성장에 기여할 수 있다. 따라서, 경제성장을 촉진하기 위한 노력과 사회개발을 위한 노력이 균 형되게 이루어질 때 개발정책에서의 성과도 커질 수 있을 것으로 생각된다.

$\mathrm{G} 20$ 개발의제는 G20이 G8 국가를 모두 포함하고 있다는 점을 고려해 볼 때 자연스럽게 G8의 개발 논의를 일정부분 계승한다고 볼 수 있다. 2009년 라퀼라 G8 정상회의와 2010년 무스코카(Muskoka) G8 정상회의에서 논의되었던 식량안보 이슈가 G20 개발 행동계획의 한 분야(pillar)로 포함되어 있는 것이 G8과 G20 개발논의의 연계를 보여주는 사례라고 할 수 있을 것이다. 앞으로도 분야에 따라서는 G8에서 논의되었던 개발 이슈가 G20으로 연결되어 신흥경제국을 포함한 보다 많은 국가 의 참여를 도모하는 사례가 생기게 될 것으로 예상된다. G7/G8이 수십년간 국제 개발논의를 주도해 온 경험과 노하우가 있는 만큼 $\mathrm{G} 20$ 도 필요에 따라 이를 잘 활용하는 것이 좋을 것으로 생각된다.

G20 개발의제는 개도국 스스로가 발전할 수 있는 여건을 갖추고 능력을 배양하는 데 중점을 둠으로 써, 개발의 효과성에 중점을 두는 최근의 논의동향과도 방향이 일치한다. 이와 관련, 지난 9월 유 엔 MDG 고위급 회의에서 오바마 대통령이 발표한 미국의 새로운 개발정책(Global Development Policy)은 단순 원조를 넘어 교육, 인프라, 기업가 정신, 무역 확대를 통한 경제성장을 통한 지속 가능한 개발을 강조하고, 선택과 집중, 공여국간 역할 분담, 수원국의 책임성, 성과, 혁신에 중점 을 두고 있어, G20의 개발의제 접근방향과도 일맥상통한다고 할 수 있다. 실제로 오바마 대통령 은 G20 서울 정상회의 개발 세션에서 미국의 새로운 개발정책과 G20의 개발의제의 접근방법이 전반적으로 일치한다고 언급한 바 있다.

또한, G20 개발의제는 2011년 부산에서 개최되는 제4차 원조효과성 고위급회의(HLF-4)와 연계되 어 고려해 볼 수 있다. 원조 효과성 증진 방안으로 남남협력의 유용성이 부각되고 있으며, OECD 원조효과성작업반(WP-EFF)에 설치된 남남협력작업팀(TT-SSC)을 중심으로 남남협력의 모범사례 분석 및 확산을 위한 논의가 진행되고 있다. G20에서도 개발의제의 모든 분야(pillar)에서 개발지 식 공유(knowledge sharing)를 주류화(mainstream)하고 개발지식 공유의 수단으로 남남협력과 삼각협력을 적극 활용하도록 하고 있다. 또한 다년간 행동계획에서는 남남협력작업팀과 UNDP가 공동으로 개발지식 공유를 확대·강화하는 방안에 대한 권고를 제출해 줄 것을 요청하고 있다. 이 와 같이 남남협력작업팀이 제4차 원조효과성 고위급회의 준비와 G20 개발 행동계획 이행을 연계 하여 추진함으로써 원조효과성 논의와 G20 개발의제가 상호보완적으로 논의될 수 있는 기회가 될 수 있을 것으로 기대된다. 


\section{3. 개발 재원 문제}

시민사회와 $\mathrm{NGO}$ 를 중심으로 한 일각에서는 $\mathrm{G} 20$ 개발의제가 재원문제에 대해서는 침묵하고 있다 는 지적이 있으나, 이는 정확한 지적이라고 하기 어렵다. 그간의 G20 정상회의는 개발재원의 중요 성을 항상 강조하여 왔다. 서울 정상회의 개발 세션 논의에서도 여러 정상과 국제기구 수장들이 개 발 재원 공약 이행의 중요성을 강조한 바 있으며, 서울 정상회의 합의문(Seoul Summit Document) 에서도 정상들은 각 회원국의 공적개발원조 공약(ODA pledges and commitments)을 이행할 것 을 재확인하고 있다.

이와 같이 G20도 개도국의 개발목표 달성 지원을 위한 원조의 중요성을 강조하고 있으나, 모든 저개발국의 개발목표 달성을 재원이 한정된 원조에만 의존하기는 어려운 것도 현실이다. 이와 관 련하여, 성장잠재력 제고를 통한 경제성장은 개도국 스스로의 개발재원 창출에 기여할 수 있다는 점을 주목할 필요가 있다. 세계경제 상황이나 공여국의 재정사정 등 여러 변수에 따라 유동성이 있는 원조에 비해 개도국 스스로의 창출하는 개발재원은 규모나 지속가능성 측면에서 보다 안정적 이라고 할 수 있다.

또한, 다년간 행동계획에서도 개발재원 문제를 다양한 방법으로 다루고 있다. 인프라 분야에서는 인프라 투자에 있어 큰 역할을 하고 있는 세계은행과 지역개발은행들이 공동으로 인프라 투자 확 대를 위한 포괄적인 행동계획을 마련하도록 하고 있다. 동 행동계획은 궁극적으로 다자개발은행의 인프라 투자 및 대출 확대를 목적으로 하고 있는 것이다. 또한, 인프라 투자를 위한 고위급 패널 (HLP)을 설립하여 공공 및 민간 재원을 활용한 인프라 투자 확대 및 다양화를 위한 구체 방안을 마련하도록 하고 있다. 식량안보 분야에서는 선시장 공약(advance market commitments) 등 혁 신적인 재원조달 메커니즘을 통해 농업생산성 향상을 위한 연구를 촉진할 수 있도록 하였다. 또 한, 라퀼라 식량안보 이니셔티브(AFSI), 글로벌농업식량안보프로그램(GAFSP) 등 기존 식량안보 및 농업개발 이니셔티브에서의 재정지원 등 약속 이행을 강조하고 있다. 특히, 서울 정상회의 합 의문에서는 기존 식량안보 프로그램에 대한 추가적인 재원 기여를 요청하고 있다.

금융소외계층 포용과 관련, G20 중소기업 자금지원 경진대회(G20 SME Finance Challenge)를 개 최하여, 중소기업에 대한 민간 자금지원 확대를 위한 혁신적인 모델을 선정하여 서울 정상회의에 서 시상하였다. 경진대회 수상사례와 성공적인 중소기업 자금지원 모델에 대한 자금지원을 위해 중소기업 자금지원 체계를 마련하였으며, 이를 통해 양허성 자금, 투자자본 및 민간자금 등을 조 달할 예정이다. 캐나다, 한국, 미국, 미주개발은행 $(\mathrm{IaDB})$ 등이 동 자금지원 체계에 양허성 지원 및 협조투융자 형태로 5.28 억불을 지원하기로 하였다. 또한, 다년간 행동계획은 개도국 내의 개발 
재원 확충에도 많은 관심을 기울이고 있다. $\mathrm{OECD}$ 와 관련 국제기구가 공동으로 개도국의 조세제 도 개혁과 탈세 방지를 통해 개도국 스스로의 개발재원을 확충하도록 하고 있다.

\section{V. 앞으로의 과제}

\section{1. 개발 행동계획의 충실한 이행과 후속과제 발굴}

서울 개발 컨센서스와 다년간 개발 행동계획 채택은 G20 개발의제 논의의 기반을 놓은 것이라고 할 수 있다. 앞으로 G20 개발 논의의 실질적인 성과는 행동계획이 얼마나 충실하게 이행되느냐에 달려 있다고 할 수 있다. 개발 행동계획에는 그 이행을 통해 바로 성과가 가시화되는 내용도 있는 반면에, 상당 부분은 향후 구체 조치 마련을 위한 분석과 권고사항 제시를 내용으로 하고 있다. 이는 개발 실무그룹 출범후 4 개월여의 짧은 기간내에 광범위한 분야에서 모두 즉각적으로 실행가 능한 구체 조치를 마련하는 것보다, 중장기적인 검토가 필요한 이슈에 대해서는 우선 연구분석 작 업을 진행한 후에 적절한 조치를 마련하는 것이 보다 현실적이라는 고려가 작용한 것이다. 이러한 경우에는 행동계획에 따른 분석과 권고사항을 토대로 추가적인 세부 조치계획을 수립하는 것이 필 요하다.

서울 정상회의 개발 관련 합의사항의 충실한 이행은 $\mathrm{G} 20$ 정상회의 그 자체를 위해서도 매우 중요 하다. G20 정상회의가 단기간에 세계경제협력의 최상위 협의체로 정착하게 된 것은 이전 회의에 서의 합의사항을 충실히 이행함으로써 국제사회의 신뢰를 얻었기 때문이다. 금융위기 이후의 세계 경제 관리(post-crisis management) 이슈로서 사실상 첫 번째의 주요 의제인 개발 분야에서도 $\mathrm{G} 20$ 에서의 합의사항은 이행된다는 전통이 이어져 나갈 때 글로벌 경제 거버넌스 체제로서 G20이 더욱 신뢰를 얻으면서 공고화되어 나갈 수 있을 것이다.

\section{G20과 국제개발기구간 상호보완적 협력 강화}

필자는 $\mathrm{G} 20$ 개발의제의 궁극적인 성공은 행동계획 이행을 넘어서, 이를 통하여 관련 분야 개발 논 의를 보완하고 시너지를 창출할 수 있는 것이어야 한다고 생각한다. 이러한 측면에서 G20과 국제 개발 행위자와의 협력이 매우 긴요하다. 많은 행동계획들이 개발 관련 국제기구를 이행주체로 설 정하고 있어 다년간 행동계획의 성공적 이행을 위해서는 국제기구와의 긴밀한 공조를 필요로 한 다. 이와 관련, 국제기구들이 다년간 행동계획 작성과정에 참여하였으며, 행동계획이 기존의 국제기 
구 프로그램을 발전시키는 제안인 경우도 많아, G20 개발 실무그룹과 국제기구와의 협력관계가 원 활히 작동되어 나갈 수 있을 것으로 기대된다.

G20 개발 실무그룹과 개발 관련 국제기구간의 커뮤니케이션이 강화될 필요가 있다. G20에는 주 요 개발 관련 국제기구들이 참여하고 있으므로 이를 적극 활용하여 G20 개발 행동계획과 관련되 는 국제 논의동향이 G20에서 적극적으로 검토되어야 할 것이다. 예를 들어 인프라 관련 G20 논 의가 효과적으로 이루어지기 위해서는 다자개발은행 등 지역 차원에서의 인프라 개발 논의가 적극 적으로 고려되어야 한다. 그렇지 못할 경우 중복적인 논의와 노력의 낭비가 발생할 수 있다. 국제 기구에서의 관련 논의에서도 G20에서의 동향이 충분히 설명되고 검토되어야 한다. 관련 국제기구 의 주요 논의에 G20 개발 실무그룹 공동의장이 참석하거나 G20 회원국중 하나가 G20에서의 논 의 동향을 설명하는 방안을 적극적으로 활용할 수 있을 것이다.

G20과 여타 국제기구는 서로의 장점을 적극 활용하여야 한다. 우선 G20은 관련 국제기구가 해당 분야에서 쌓아온 성과와 전문성을 최대한 활용하는 것이 바람직하다. 그동안 축적된 국제논의의 성과물을 활용하는 것은 $\mathrm{G} 20$ 에서의 논의의 정당성과 효율성을 위해서도 도움이 될 것으로 생각된 다. 한편, 여타 국제기구는 G20을 활용하여 소관 개발 이슈에 관한 국제사회의 관심을 환기하고 정치적 동력을 강화할 수 있다. G20에서의 논의 결과는 그 회원국들이 국제 정치·경제에서 차지 하는 비중을 보았을 때 자연스럽게 국제적인 관심의 대상이 되며, G20은 다른 국제기구와는 달리 정상들이 정기적으로 회동함으로써 최고위 수준의 정치적인 모멘텀을 제공한다. 따라서, G20을 적절히 활용하면, 국제기구는 중요한 개발 이니셔티브 추진에 필요한 인적 자원, 재원을 보다 용 이하게 확보할 수도 있을 것이다. 또한, G20은 개발 문제와 밀접히 연계되는 무역, 에너지, 금융, 거시경제, 반부패 등 여러 이슈를 다루고 있다. 개발 문제를 보다 포괄적인 시각에서 조망할 때, 분야간 시너지를 창출할 수 있는 정책대안을 마련할 수 있을 것이다. 국제기구는 G20 논의 참여 를 통해 다른 이슈와 연계하여 효과적으로 개발 이슈를 추진하는 방안을 마련하는 데 도움을 받을 수 있을 것으로 생각된다.

다시 말해, G20은 분야별로 주요 행위자와 이니셔티브를 통합하여 적극적으로 공조하도록 하고 있으며, 여타 정책 분야와 연계하여 개발 문제를 다룰 수 있도록 한다. 따라서 앞으로 이러한 행 위자와 이니셔티브간 공조와 협력, 그리고 정책이슈간 연계가 효과적으로 이루어질 때, G20이 분 야별로 분산되어 추진되어 오던 국제개발협력을 종합적으로 일관성 있게 추진되도록 촉진하는 역 할을 할 수 있을 것으로 기대된다. 


\section{3. 개도국 입장의 지속적인 반영}

개발논의가 효과적이고 현실성 있게 진행되기 위해서는 개발의 당사자인 개도국, 특히 저소득국의 우려와 관심사항을 충분히 고려하는 것이 중요하다. G20은 개발의제 논의 과정에서 이들 국가와 의 대화를 매우 중시해 왔다. 우리나라는 의장국으로서 UN, 아프리카, 아시아, 중남미 등에서의 활발한 아웃리치 활동을 통해 개발 문제를 중심으로 G20의 논의동향을 설명하고 비회원국들의 의 견을 적극적으로 수렴하였다. 이러한 과정에서 개도국들은 G20의 개발의제 추진에 대한 지지를 보여주었고, 아프리카의 경우 여러 국가에 걸친 지역 인프라(regional infrastructure)의 중요성 등 구체적인 의견을 제시해 주었다. 또한, 개발 실무그룹은 말라위(AU 의장국), 에티오피아, 베트 남(ASEAN 의장국), 싱가포르 등 G20 정상회의 초청국들이 개발 실무그룹 회의에도 참석하도록 하여 이들의 의견도 반영하였다.

서울 정상회의 개발 분야 성과에 대해 개도국들이 전반적으로 환영의 입장을 표한 만큼, 향후 개 발 행동계획이 어떻게 이행되고 개도국들에 얼마나 실질적인 도움이 되느냐에 대한 이들 국가들의 관심은 더욱 높아질 것으로 생각된다. 행동계획의 이행이 개도국에서의 현실을 반영하여 이루어지 기 위해서는 개도국들과 상시적인 대화의 통로를 열어 두어야 할 것이다. 또한 위에서 언급하였듯 이 개발 행동계획의 상당부분은 현재 상황에 대한 분석을 토대로 향후 필요한 추가적인 조치를 발 굴하는 데 있으므로 현실성 있는 후속조치가 되기 위해서는 개도국들의 의견을 실질적으로 반영할 수 있는 노력이 필요하다. 이를 위해서는 2011년 개발 실무그룹 공동의장을 수행할 예정인 프랑 스, 한국, 남아공이 적극적으로 아웃리치 활동을 수행하고, 지역사정을 잘 아는 지역개발은행들이 보다 적극적으로 아프리카 등 지역의 관심사를 개발 실무그룹 논의에 반영하기 위한 노력을 강화 해야 할 것으로 생각된다.

\section{4. 시민사회 및 NGO와의 대화}

국제 개발논의에서 시민사회 및 민간기관의 역할과 영향력이 점점 커지고 있는 만큼 개발 문제에 관해 $\mathrm{G} 20$ 과 시민사회 및 $\mathrm{NGO}$ 와의 대화도 강화되어 나가야 할 것이다. 우리나라는 2010년 의장 국으로서 지난 10 월 G20 셰르파회의 직후 셰르파들과 각국의 시민사회 대표가 참석한 가운데 시 민사회와의 대화(Civil G20 Dialogue)를 개최하고, 여타 개발 $\mathrm{NGO}$ 와의 대화를 수차례 개최하는 등 시민사회의 의견을 반영하기 위한 노력을 전개한 바 있다. 이와 유사한 노력이 금년에는 보다 강화될 수 있기를 기대한다. 이러한 노력을 통해 G20 개발의제에 대한 바른 이해가 확산될 수 있 을 것이며, 이는 향후 $\mathrm{G} 20$ 개발의제가 국제사회의 지지를 받으면서 보다 발전적인 방향으로 진전 되어 나가는데 기여할 수 있을 것이다. 


\section{VI. 맺음말 : 우리나라 개발외교 정책에 대한 시사점}

금번 서울 개발 컨센서스와 행동계획 합의는 국제개발 논의에서 우리나라의 역할이 더욱 확대되고 있다는 측면에서도 매우 큰 의의가 있다. 우리나라는 금년부터 $\mathrm{OECD} \mathrm{DAC}$ 의 정식 회원국이 되었 다. 또한 2011년 11월 29일 - 12월 1일간 부산에서 제4차 원조효과성 고위급회의(HLF-4)가 개최 될 예정이다. 이러한 가운데 우리나라가 G20 의장국으로서 서울 개발 컨센서스를 제시하는 데 주 도적 역할을 함으로써 국제개발체제에서 빠질 수 없는 중요한 행위자의 하나로 부상했다고 할 수 있다.

국제사회는 우리나라가 금년도 G20 의장국으로서 개발을 G20의 주요의제로 도입하는 데 주도적 인 역할을 하였다는 것을 높이 평가하고 있다. 서울 정상회의 개발 세션에서도 한 세대만에 최빈 국에서 $\mathrm{OECD}$ 개발원조위원회(DAC) 회원국으로 발전한 성공적인 개발경험을 가지고 있는 우리나 라에서 G20 서울 개발 컨센서스와 다년간 행동계획이 채택된 것을 매우 의미있다고 평가해 주었 다. 그만큼 $\mathrm{G} 20$ 개발의제가 향후 성공적으로 이행되고 정착되어 나가는 노력에 있어서도 우리나 라의 역할에 대해 국제사회, 특히 개도국들이 큰 기대를 가지고 있는 것이다.

우리나라는 G20 개발의제의 성공에 기여할 수 있는 좋은 여건을 갖추고 있다. 무엇보다도 G20 개발의제의 기본 방향이 우리나라의 개발경험과 일맥상통한다고 할 수 있다. 이러한 성공적인 경 험의 주요 내용이 서울 개발 컨센서스에 담겨 있으며, 우리가 추진했던 많은 정책들이 다년간 행 동계획에도 포함되어 있다. 우리나라는 향후 G20 개발의제가 개도국의 개발정책에 실제로 적용되 어 나가는 과정에서 우리의 경험을 공유하면서 이들 국가의 사정에 적합한 정책을 마련하여 추진 해 나갈 수 있도록 적극 지원해 나가야 할 것이다.

우리나라의 개발외교 정책도 $\mathrm{MDG}$ 로 대표되는 국제사회 공동의 개발목표 달성 지원에 중점을 두 고, $\mathrm{OECD} \mathrm{DAC}$ 의 주요 원칙, 원조효과성에 관한 파리선언과 아크라행동계획 등에 기반을 두면서 개발의 효과성에 초점을 두는 방향으로 종합적인 개발정책을 추진해 나갈 필요가 있을 것이다. 개 발목표 달성이 성공적으로 이루어지기 위해서는 개발에 관련되는 폭넓은 분야에서 상호 보완적이 고 종합적인 정책적 노력이 필요하다. 개도국들이 개발의 한 측면에만 초점을 맞추기보다는 개발 의 효과성 증진에 기여할 수 있는 종합적인 전략을 추진할 수 있도록 지원해 나가는 것이 바람직 하다. 이러한 점을 고려하여 우리나라의 개발외교정책 추진에 있어서도 보다 다양하고 종합적인 정책수단을 활용해 나가는 것이 좋을 것으로 생각된다. 
한편, G20 개발의제를 발전시켜 나가는 과정에 있어 우리나라는 공동의장국으로서 회원국, 비회 원국, 국제기구뿐만 아니라 유수의 국제적인 연구기관과의 협의도 적극 활용하였다. 우리나라에도 G20 개발의제를 포함한 전체적인 개발외교 추진을 뒷받침할 수 있도록 외교부 산하에 개발연구센 터 설치가 필요하다. 우리 개발외교의 범위가 확대되고 있는 가운데 국제 개발협력 동향을 연구하 고 우리 개발협력의 발전방향을 제시할 수 있는 세계적인 수준의 개발 문제 연구기관을 설치하는 것은 한국 개발협력의 선진화에 절대적으로 필요하다고 할 것이다. 